University of Nebraska - Lincoln

DigitalCommons@University of Nebraska - Lincoln

\title{
Atrazine Transport Within a Coastal Zone in Southeastern Puerto Rico: a Sensitivity Analysis of an Agricultural Field Model and Riparian Zone Management Model
}

\author{
Candiss O. Williams \\ Richard Lowrance \\ National Risk Management Research Laboratory \\ Thomas Potter \\ Southeast Watershed Research Laboratory \\ David D. Bosch \\ Southeast Watershed Research Laboratory \\ Timothy Strickland \\ Southeast Watershed Research Laboratory
}

Charles E. Kellogg National Soil Survey and Research Laboratory, Candiss.williams@lin.usda.gov

Follow this and additional works at: https://digitalcommons.unl.edu/usdaarsfacpub

Williams, Candiss O.; Lowrance, Richard; Potter, Thomas; Bosch, David D.; and Strickland, Timothy, "Atrazine Transport Within a Coastal Zone in Southeastern Puerto Rico: a Sensitivity Analysis of an Agricultural Field Model and Riparian Zone Management Model" (2016). Publications from USDA-ARS / UNL Faculty. 2103.

https://digitalcommons.unl.edu/usdaarsfacpub/2103

This Article is brought to you for free and open access by the U.S. Department of Agriculture: Agricultural Research Service, Lincoln, Nebraska at DigitalCommons@University of Nebraska - Lincoln. It has been accepted for inclusion in Publications from USDA-ARS / UNL Faculty by an authorized administrator of DigitalCommons@University of Nebraska - Lincoln. 


\title{
Atrazine Transport Within a Coastal Zone in Southeastern Puerto Rico: a Sensitivity Analysis of an Agricultural Field Model and Riparian Zone Management Model
}

\author{
Candiss O. Williams ${ }^{1}$ (D) Richard Lowrance ${ }^{2} \cdot$ Thomas Potter $^{3}$ - David D. Bosch ${ }^{3}$. \\ Timothy Strickland ${ }^{3}$
}

Received: 3 September 2015 / Accepted: 8 March 2016/Published online: 22 March 2016

(C) Springer International Publishing Switzerland (outside the USA) 2016

\begin{abstract}
Agrichemical runoff from farmland may adversely impact coastal water quality. Two models, the Agricultural Policy/Environmental eXtender (APEX) and the Riparian Ecosystem Management Model (REMM), were used to evaluate the movement of the herbicide atrazine to the Jobos Bay National Estuarine Research Reserve from adjacent fields. The reserve is located on Puerto Rico's southeast coast. Edge-of-field atrazine outputs simulated with the APEX were routed through a grass-forest buffer using the REMM. Atrazine $\mathrm{DT}_{50}$ (half-life) values measured in both field and buffer soils indicated that accelerated degradation conditions had developed in the field soil due to repeated atrazine application. APEX simulations examined both the measured field and buffer soil atrazine $\mathrm{DT}_{50}$ and the model's default value. The use of the measured field soil atrazine degradation rate in the APEX resulted in $33 \%$ lower atrazine transport from the field. REMM simulations indicated that the buffer system had the potential to reduce dissolved atrazine transport in surface runoff by $77 \%$ during non-tropical storm events by increasing infiltration, slowing transport, and increasing time for pesticide degradation. During a large runoff event due to a tropical storm that occurred close to the time of an atrazine application, the REMM simulated only a $37 \%$ reduction in atrazine
\end{abstract}

Candiss O. Williams

candiss.williams@lin.usda.gov

1 Charles E. Kellogg National Soil Survey and Research Laboratory, 100 Centennial Mall North, Lincoln, NE 68508, USA

2 National Risk Management Research Laboratory, 919 Kerr Research Road, Ada, OK 74820, USA

3 Southeast Watershed Research Laboratory, 2379 Rainwater Road, Tifton, GA 31794, USA transport. The results indicate that large storm events soon after herbicide application likely dominate herbicide transport to coastal waters in the region. These results agree with water quality measurements in the reserve. This study demonstrated the sensitivity of these models to variations in $\mathrm{DT}_{50}$ values in evaluating atrazine fate and transport in the region and emphasizes that the use of measured $\mathrm{DT}_{50}$ values can improve model accuracy.

Keywords Water quality $\cdot$ Hydrology $\cdot$ Wetlands · Conservation Effects Assessment Project · Tropical estuary · Predictive models

\section{Introduction}

The recent work in Australia has shown that residues of atrazine (6-chloro- $N 2$-ethyl- $N 4$-isopropyl-1,3,5-triazine-2,4-diamine) and other herbicides in streams and rivers that drain agricultural uplands may threaten coastal ecosystems [1]. Numerous studies have also shown that herbicide transport to surface waters may be reduced through the use of conservation practices such as riparian buffers [2-5]. Riparian buffers have been adopted as a best management practice (BMP) in non-point source pollution control programs [6, 7] and are part of the United States Department of Agriculture (USDA)'s Conservation Reserve Program. Herbaceous vegetative strips can also be effective in reducing herbicide loads $[3,8-10]$ and can be incorporated into riparian forest buffer specifications. The original USDA riparian forest buffer specification included an herbaceous (usually grass) filter strip between the source area (field) and the forest buffer [11, 12].

To our knowledge, there have been few assessments on the efficacy of vegetated buffers in reducing agrichemical transport in coastal zones particularly in tropical regions. Because 
much of the agriculture in Puerto Rico is in coastal plain areas adjacent to ecologically sensitive coastal waters, movement of atrazine and other agrichemicals from farm fields into coastal waters is a concern $[13,14]$. Jobos Bay National Estuarine Research Reserve (JBNERR) in south central Puerto Rico is typical of these areas. Because of the importance of understanding the non-point source pollution impacts of agriculture on coastal waters, the Jobos Bay Watershed was selected as a USDA-Natural Resources Conservation Service (NRCS) Conservation Effects Assessment Project (CEAP) Special Emphasis Watershed in 2008. CEAP is a nationwide project led by the USDA to quantify environmental effects of conservation practices on water quality and quantity at the national scale [15]. As a Special Emphasis Watershed, the Jobos Bay CEAP was designed to be a short-term (3-year) study to evaluate the environmental effects of conservation practices on coastal waters and associated habitats in a tropical ecosystem.

Process-based simulation models are useful tools in predicting transport mechanisms of agricultural chemicals on a landscape scale as well as in evaluating the effectiveness of conservation practices over time [16]. The USDA has recognized that process-based models are valuable tools for extrapolating regional findings to a national assessment. An important component of simulation model effectiveness is site-specific parameterization which reduces prediction uncertainty [17]. For pesticides, a key parameter is the degradation/dissipation rate. Sensitivity analyses have concluded that dissipation parameters may have the greatest impact on the ability of model simulations to reflect measured data [18-20]. Default values derived from published studies and/or documents used to support pesticide registrations are often used to describe dissipation kinetics. However, values may not reflect field conditions, especially in cases where accelerated dissipation may develop following a repeated application of a pesticide [21] causing soil to "adapt." For example, Krutz et al. [22] observed a 10-fold decrease in atrazine $\mathrm{DT}_{50}$ (half-life) in soils from Colorado and Mississippi when they compared adapted and nonadapted soils. These rates were 18-fold lower than the values used by the US Environmental Protection Agency (USEPA) in atrazine risk assessments [22]. Potter et al. [14] reported that accelerated atrazine dissipation conditions had developed in the silage field at the study location.

Riparian buffers have been shown to be effective in mitigating the transport of agricultural pollutants to adjacent water bodies [10-12]. With limited information on the impact of three-zone riparian buffers on atrazine transport in tropical ecosystems where tropical storms play an important role, it was important to determine the effectiveness of a three-zone buffer system as a potential conservation program to mitigate atrazine transport. In this study, we evaluated the sensitivity of the Agricultural Policy/Environmental eXtender (APEX) to $\mathrm{DT}_{50}$ input values to output from the fields and the effectiveness of a three-zone buffer system on atrazine transport with the Riparian Ecosystem Management Model (REMM).

\section{Materials and Methods}

In this evaluation, the APEX [23] and the REMM [24, 25] were used in tandem to simulate waterborne atrazine transport (dissolved and sediment bound) from an upland field through a three-zone buffer with grass and forest vegetation. The APEX simulated upland transport to the buffer zone and REMM transport within and through the buffer zone. Both the APEX and REMM were calibrated and validated for the farm fields and buffer using soil and hydrologic data from the site [26]. Measured atrazine dissipation in the field and riparian soils of the site were also used [14].

\subsection{Study Site}

The study site is within the Central Aguirre Watershed, a subwatershed within the Jobos Bay Watershed in south central Puerto Rico $\left(17^{\circ} 56^{\prime} 36^{\prime \prime} \mathrm{N}\right.$ and $\left.66^{\circ} 13^{\prime} 45^{\prime \prime} \mathrm{W}\right)$, about $5.6 \mathrm{~km}$ (3.5 miles) southeast of Salinas, Puerto Rico (Fig. 1). The climate is tropical with a mean annual precipitation of $991 \mathrm{~mm}$ (39 in.) (1971-2000) and a mean annual temperature of $26^{\circ} \mathrm{C}$, with a maximum of $28.6^{\circ} \mathrm{C}$ in August and a minimum of $22.4^{\circ} \mathrm{C}$ in January [27]. Seasons are defined as dry (November-May) and wet (June-October) with the wet season corresponding to the Atlantic hurricane season. The study focused on a 108-ha (267-ac) irrigated agricultural field and an adjacent vegetated buffer adjacent to JBNERR (Fig. 1). When the Jobos Bay Watershed was designated a CEAP Special Emphasis Watershed by the USDA-NRCS, farm operators agreed to provide management data and facilitate hydrologic and water quality monitoring by USDA, JBNERR, and cooperators.

Field soils are predominantly in the Cartagena and Ponceña Soil Series. Cartagena clay soils are very deep and somewhat poorly drained, and Ponceña clay soils are moderately well drained [28]. Both soils were formed in clayey sediments weathered from volcanic rocks and limestone. Cartagena soils are found in low-lying areas and are sodium enriched, while the Ponceña soils are in slightly higher topographic positions. Both the Ponceña and Cartagena soils are classified as hydrologic soil group D (poorly drained).

The farm was under center pivot irrigation for the first 2 years of study (2008-2009) and was divided into four quadrants of 27 ha $(67 \mathrm{ac}$ ) each (Fig. 1). All were under reduced till. Multiple crops of corn (Zea mays L.), sorghum (Sorghum bicolor L.), and/or cow peas (Vigna sinensis L.) were grown in each subarea in 2008 and 2009. Because each quadrant was 
Fig. 1 Study site in southern Puerto Rico showing the location of the fields, the riparian buffer, and the mangrove wetland

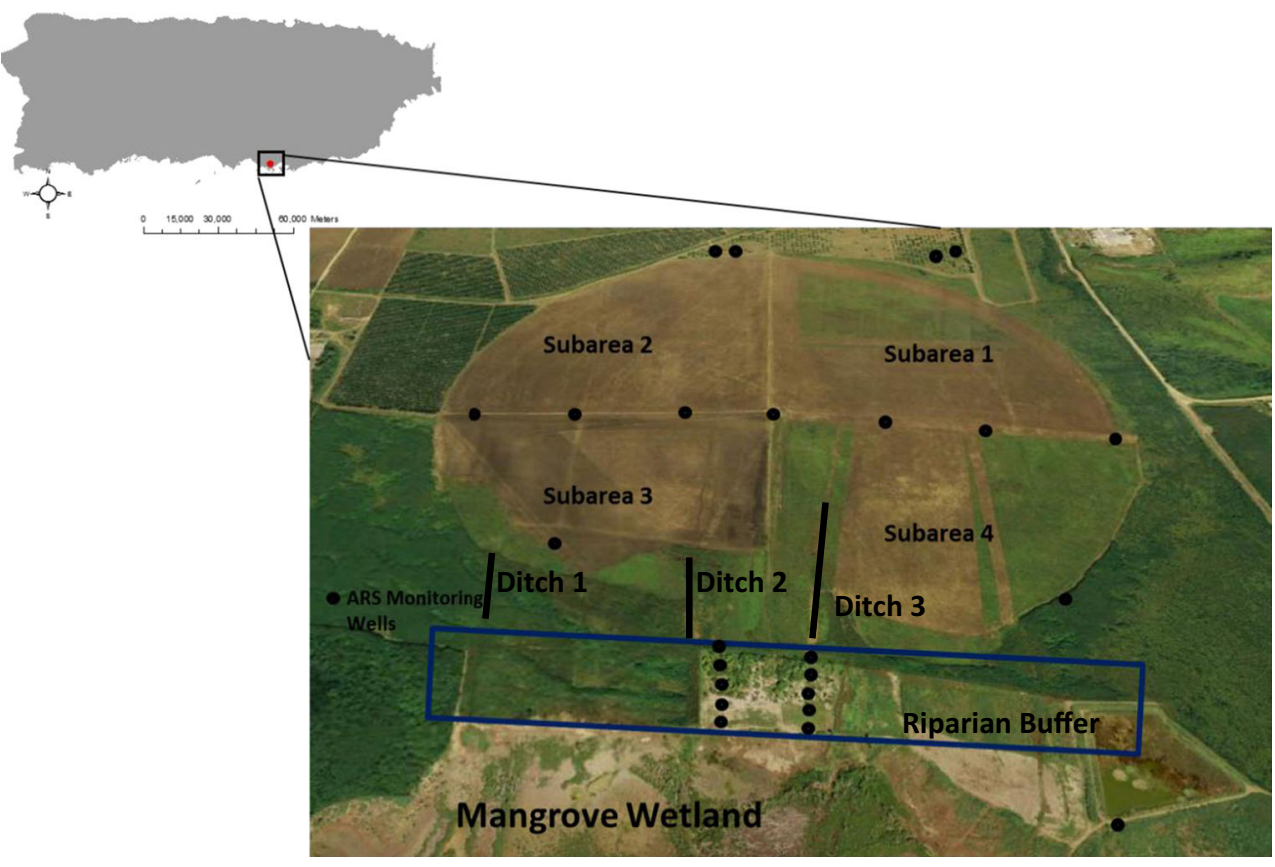

managed differently, each was considered a subwatershed in the APEX and will be referred to as SA1 through SA4 (SA1, SA2, SA3, and SA4) (Fig. 1). Crops were not grown in 2010, and there were no agrichemicals applied because the irrigation system was not functioning.

Each subarea had multiple pesticide, fertilizer, and irrigation management operations for each planting. For the simulation period, subareas had an average of three plantings per year (Table 1). During the study period, individual preemergence atrazine applications ranged up to $962 \mathrm{~g} \mathrm{ha}^{-1}$ $\left(0.86 \mathrm{lb} \mathrm{ac}^{-1}\right)$ for each subarea with an annual average of $4760 \mathrm{~g} \mathrm{ha}^{-1}$ (4.25 $\mathrm{lb} \mathrm{ac}^{-1}$ ) for all four subareas in 2008 and 2009 (Table 1). The total mass of atrazine active ingredient (AI) applied to the entire silage field during the study period was $514 \mathrm{~kg}$ (1133 lb). Commercial atrazine formulations were tank mixed with other herbicides and broadcast sprayed; there was no incorporation. Additional details of the farm management are given in [26].

Three drainage ditches cross the buffer area and create a hydrologic connection between the field and Mar Negro's tidal flats (Fig. 1). The drainage ditches were simulated in the APEX with an output from SA3. The flows that bypassed the riparian buffer were not simulated separately using the REMM because of model limitations, and all of the flow was simulated as if it went through the riparian buffer. The concentrated flow simulated from the upland field was distributed and simulated as overland and subsurface flows within the buffer.

The 16-ha (40-ac) buffer zone is situated in an area which lies between the farm field and the mangrove forest located on the landward edge of JBNERR (Fig. 1). The buffer soils are classified as tidal flats (TFs) which consist of low-lying areas, slightly above sea level, that are affected by seawater during storm tides. The TF soils averaged $43 \%$ clay, $28 \%$ sand, and

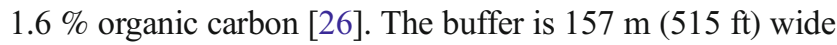
from the upland field to the mangroves (perpendicular to the mangroves) and $1039 \mathrm{~m}$ (3409 ft) long (the dimension along the mangroves).

\subsection{Use of APEX and REMM}

Daily outputs from the APEX were used as daily inputs to the REMM. The APEX simulated the quadrants of the field as four separate fields (subareas). Upland fields SA1, SA2, and SA4 drained into SA3 which then became input for the REMM. The hydrologic component of the APEX [29] consists of all key processes that occur in the hydrologic cycle. Incoming precipitation may be intercepted by plant canopies, and when rainfall exceeds interception, the excess falls to the soil surface. Precipitation is then partitioned between surface runoff and infiltration. The surface runoff model in the APEX simulates runoff volumes and peak runoff rates, given daily rainfall amounts. There are two methods the user can choose from, the modified Soil Conservation Service (SCS) curve number technique [30] or the Green Ampt infiltration equation [31]. For this study, we chose the SCS curve number technique due to its reliability and relationship to soil type, land use, and management practices. The subsurface flow model includes vertical and horizontal components which are computed simultaneously using storage routing and pipe flow equations. The vertical or percolation component flows to groundwater storage and is subject to deep percolation and return flow. Return flow is added to channel flow from a subarea. Horizontal flow is partitioned into lateral and quick 
Table 1 Planting, harvesting, and atrazine application schedule

\begin{tabular}{|c|c|c|c|c|c|c|}
\hline Year & $\begin{array}{l}\text { Subarea } \\
\text { ID }\end{array}$ & Crop & Plant & Harvest & $\begin{array}{l}\text { Atrazine applied } \\
\left(\mathrm{g} \mathrm{ha}^{-1}\right)^{\mathrm{a}}\end{array}$ & $\begin{array}{l}\text { Atrazine } \\
\text { application date }\end{array}$ \\
\hline 2008 & SA1 & Corn & 5 February & 26 April & 962 & 28 February \\
\hline 2008 & SA1 & Corn & 29 April & 15 July & 962 & 29 April \\
\hline 2008 & SA1 & Corn & 30 October & 19 & 1292 & $\begin{array}{l}30 \text { October, } 13 \\
\text { and } 28 \\
\text { November }\end{array}$ \\
\hline 2009 & SA1 & Cowpea & 8 April & $\begin{array}{l}\text { Tilled } \\
\text { under }\end{array}$ & 0 & \\
\hline 2010 & SA1 & Fallow & & & & \\
\hline 2008 & SA2 & Corn & 18 January & 20 March & 962 & 19 March \\
\hline 2008 & SA2 & Sorghum & 21 May & 15 August & 962 & 14 June \\
\hline 2008 & $\mathrm{SA} 2$ & Corn & $\begin{array}{l}16 \\
\text { December }\end{array}$ & 2 February & 1443 & 16 December \\
\hline 2009 & SA2 & Corn & 1 June & 31 August & 1924 & 1 and 26 June \\
\hline 2009 & $\mathrm{SA} 2$ & Sorghum & 14 September & ${ }^{7}$ December & 721 & 17 September \\
\hline 2010 & SA2 & Fallow & & & & \\
\hline 2008 & SA3 & Sorghum & 19 March & 23 July & 962 & 19 March \\
\hline 2008 & SA3 & Sorghum & 26 July & ${ }^{25}$ September & 1924 & $\begin{array}{c}31 \text { July, } 12 \\
\text { August }\end{array}$ \\
\hline 2008 & SA3 & Sorghum & 27 September & 7 December & 0 & \\
\hline 2009 & SA3 & Sorghum & 4 February & 24 March & 962 & 5 February \\
\hline 2009 & $\mathrm{SA} 3$ & Sorghum & 26 June & 22 September & 1443 & 26 June, 14 July \\
\hline 2009 & SA3 & Sorghum & 26 October & 7 December & 962 & 9 November \\
\hline 2010 & SA3 & Fallow & & & 0 & \\
\hline 2008 & SA4 & Sorghum & 18 January & 26 April & 0 & 26 April \\
\hline 2008 & SA4 & Sorghum & 29 April & 30 June & 962 & \\
\hline 2008 & SA4 & Sorghum & 4 November & 4 January & 1924 & $\begin{array}{l}4 \text { and } 25 \\
\text { November }\end{array}$ \\
\hline 2009 & SA4 & Sorghum & 18 January & 20 May & 0 & \\
\hline 2009 & SA4 & Sorghum & 17 July & 7 October & 721 & 27 July \\
\hline 2009 & SA4 & Sorghum & 12 October & 7 December & 0 & \\
\hline 2010 & SA4 & Fallow & & & & \\
\hline
\end{tabular}

${ }^{a}$ Grams per hectare of the active ingredient was applied to the field. Each field is 27 ha in size. Atrazine applied is the sum for multiple applications return flow. Lateral subsurface flow enters the subarea immediately downstream and is added to that subareas' soil and water storage. Quick return flow is added to the channel flow from the subarea. The storage routing technique in the APEX allows flow from one soil layer to another when soil water content exceeds field capacity. Water drains from a layer as a function of layer storage and saturated conductivity until the storage returns to field capacity. Routing mechanisms also provide evaluation of interactions between subareas that involve surface and subsurface flows. Once overland processes have been simulated, the APEX routes water, sediment, nutrients, and pesticides across complex landscapes and channel systems to a watershed outlet. As a USDA CEAP Special Emphasis Watershed, this study was designed to be short term; therefore, a principal limitation was not having automated equipment to monitor surface flows. However, we did observe early that flows in the ditch were limited to storm events during the wet season (June-October) which corresponds to the Atlantic hurricane season.

The REMM simulated the buffer system in three distinct zones. The wide of zone 1 (nearest the estuary) was $77 \mathrm{~m}(253 \mathrm{ft})$, and the width of zone 2 was $40 \mathrm{~m}(131 \mathrm{ft})$. Vegetation in both zones was mostly leadtree (Leucaena leucocephala de Wit.), devil's horsewhip (Achyranthes aspera L.), and Egyptian river hemp (Sesbania sesban L. Merr.). Zone 3, which is furthest away from the mangroves, was $40 \mathrm{~m}$ (131 ft) wide and was covered with perennial grasses, primarily Guinea grass (Megathyrsus 
maximus Jacq.), signal grass (Urochloa distachya (L.) T.Q. Nguyen), and Johnson grass (Sorghum halepense L. Pers.). The slope length of the 108-ha (267-ac) contribut-

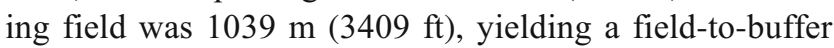
area ratio of approximately $7: 1$. The ground surface slope from the upland field to the zone, where mangrove vegetation was predominant, was $1 \%$.

The REMM took upland outputs: surface runoff; subsurface flow; sediment yield; N, P, and C; pesticide in surface runoff, subsurface flow, and sediment generated by the APEX; and calculated loadings of water, nutrients, pesticides, sediment, and carbon based on the actual area of the zones in the buffer system. The APEX was executed three times with $\mathrm{DT}_{50}=18,55$, or 146 days. The $\mathrm{DT}_{50}$ values reflected measured values in field and buffer soils and the default value in APEX, respectively. The $\mathrm{DT}_{50}$ used in the REMM was the measured value in buffer soil. Other REMM inputs included daily weather (the same as those for the APEX), soil, plant, and litter properties by layer; vegetation type by zone and initial conditions for soil including physical and hydrologic properties; and initial carbon and nutrient pools. Other APEX model inputs included crops grown, planting and harvesting dates, tillage type and dates, and fertilizer and pesticide applications.

Weather measurements (minimum and maximum temperature, daily total solar radiation, precipitation, relative humidity, and wind speed) were obtained from a HOBO (Onset Computer Corp., Bourne, MA) weather station that was installed in 2008 (Fig. 1). Precipitation was measured using an Onset rain gauge smart sensor tipping bucket, wind speed was measured using an Onset wind speed and direction smart sensor, temperature and relative humidity were measured using an Onset temperature and relative humidity smart sensor, and solar radiation was measured using an Onset silicon pyranometer smart sensor, all of which were connected to an Onset Hobo Event logger. When data from the site were missing (January 2007 and December 2008), weather data were used from [32], a weather station which is $2 \mathrm{~km}$ (1.2 miles) away from the study location.

Soil layer depth, $\mathrm{pH}$, percent organic carbon, bulk density, field capacity, wilting point, percentage sand and silt, saturated conductivity, cation exchange capacity, sum of bases, calcium carbonate content, and soil albedo were measured in the cultivated farm field by the USDA-NRCS [33] and in the riparian zone by the USDA-ARS, specifically for this study. Soils in the cultivated field were sampled by genetic horizons to a depth of $200 \mathrm{~cm}$ (79 in.) [33], and soils in the riparian zone were sampled in 10-cm (4-in.) increments to a depth of $140 \mathrm{~cm}(55 \mathrm{in}$.). The saturated hydraulic conductivity of the cultivated farm field and riparian buffer zone soil layers was estimated with the Rosetta model [34] using measurements of percentages of sand, silt, and clay; bulk density; and water retention at 33 and $1500 \mathrm{kPa}$.

\subsection{Calibration and Validation of APEX and REMM}

The hydrologic calibration and validation of both models are described in [26]. The APEX was calibrated for each subarea (Fig. 1) and the REMM for the buffer. The average simulated depths to water table for each subarea were within $\pm 9 \%$ of the corresponding observed values with the exception of SA2 for the validation period [26]. SA2 during the validation period was not cultivated and had substantial weed growth and volunteer sorghum regrowth. The APEX underpredicted the depth to the water table likely as a result of underestimated plant biomass and associated transpiration. REMM average simulated depths to the water table for the buffer area were within $\pm 4 \%$ of the corresponding observed values for both the calibration and validation periods [26].

APEX and REMM parameters used to evaluate the sensitivity of $\mathrm{DT}_{50}$ values for atrazine included solubility (33 parts per million), soil organic matter sorption coefficient $\left(K_{\mathrm{oc}}, 100\right)$, and atrazine $\mathrm{DT}_{50}$ in soil (days) $(18,55$, and 146 days for the APEX and 55 days for the REMM). No further calibration beyond the hydrologic calibration described in [26] was conducted. Atrazine and atrazine degradation product concentrations were determined in monthly groundwater samples from wells in the silage field and were previously reported [14]. However, the APEX does not compute groundwater concentrations so calibration/validation with the groundwater concentration data was not possible. Limited surface runoff concentration data were available due to farming constraints [14].

Pesticides in the APEX and REMM can be intercepted by plant leaves, bound in soil, leached, transported in runoff water or on sediment in runoff [23]. The REMM is described in [35] and the REMM pesticide module in [36]. Pesticide transport in both the APEX and REMM is related to hydrology and sediment transport and is controlled by the amount of pesticide in soil and water pools. In turn, the amount of pesticide in the soil and water pools is controlled by soil sorption and desorption and dissipation. Dissipation in both models is described with a firstorder kinetic equation with $\mathrm{DT}_{50}=\ln (2) / k$ where $k$ is the dissipation rate constant. Rate constants are adjusted for temperature and soil moisture. Because dissipation for pesticides may vary widely among soils and climate regimes [18-20], it is recommended that field-measured rates be used in model simulations [18-20]. This is especially true in tropical climates where dissipation may be more rapid [21, 37].

For this study, the measured atrazine $\mathrm{DT}_{50}$ averaged 18 and 55 days for the field soil and the buffer soil, respectively [14]. As noted, the difference between the field and buffer soil values was linked to accelerated atrazine degradation in the field soil after repeated atrazine applications [14]. 


\subsection{Statistical Analysis}

To compare atrazine loading between simulations, the data were tested for normal distribution using the Univariate Procedure in SAS [38]. The data were not normally distributed so non-parametric analyses were performed on atrazine loading data from the three APEX simulations and the three REMM simulations (based on the APEX loads into the REMM). The NPAR1WAY Procedure of SAS with the Kruskal-Wallis test [38] was used to test whether the loading scenarios had an effect on atrazine transport and to test whether the atrazine loading rates between the three positions in the REMM-simulated buffer (exiting zone 3, exiting zone 2, and exiting zone 1) were different from one another.

\section{Results and Discussion}

\subsection{APEX Simulated Atrazine Transport}

Total atrazine transport is reported for the entire simulation period (2008-2010) on a mass or mass per area basis. Simulated transport of atrazine in surface runoff (APEX) was significantly different $(p<0.001)$ among the three simulations for the three atrazine $\mathrm{DT}_{50}$ values (Table 2$)$. There was a significant difference $(p<0.001)$ between the upland field as simulated using the APEX compared to each of the three riparian zone outlets as simulated by the REMM. Differences in outputs were up to $33 \%$. Daily atrazine mass

Table 2 Mass of atrazine transported from the upland field (APEX), the buffer (REMM), and percent reduction in the simulated buffer for the study period (2008-2010)

\begin{tabular}{llll}
\hline APEX DT $_{50}($ days $)$ & Upland field & Buffer & $\%$ reduction \\
\hline Surface runoff $\left(\mathrm{g} \mathrm{ha}^{-1}\right)$ & & & \\
18 & $41^{\mathrm{a}}$ & $9.2^{\mathrm{a}}$ & 77 \\
55 & $54^{\mathrm{b}}$ & $14^{\mathrm{a}}$ & 75 \\
146 & $60^{\mathrm{b}}$ & $17^{\mathrm{a}}$ & 71 \\
Subsurface flow $\left(\mathrm{g} \mathrm{ha}^{-1}\right)$ & & & \\
18 & $0.02^{\mathrm{a}}$ & $0.00^{\mathrm{a}}$ & 100 \\
55 & $0.02^{\mathrm{a}}$ & $0.00^{\mathrm{a}}$ & 100 \\
146 & $0.03^{\mathrm{a}}$ & $0.00^{\mathrm{a}}$ & 100 \\
Sediment bound $\left(\mathrm{g} \mathrm{ha}^{-1}\right)$ & & \\
18 & $0.17^{\mathrm{a}}$ & $0.08^{\mathrm{a}}$ & 50 \\
55 & $0.26^{\mathrm{a}}$ & $0.13^{\mathrm{a}}$ & 50 \\
146 & $0.46^{\mathrm{a}}$ & $0.27^{\mathrm{a}}$ & 42 \\
\hline
\end{tabular}

Dissolved atrazine in surface runoff (APEX) among DT 50 was significantly different $(p<0.001)$ based on the Kruskal-Wallis test for 18-day $\mathrm{DT}_{50}$

For the upland field and buffer, values with the same letter are not significantly different
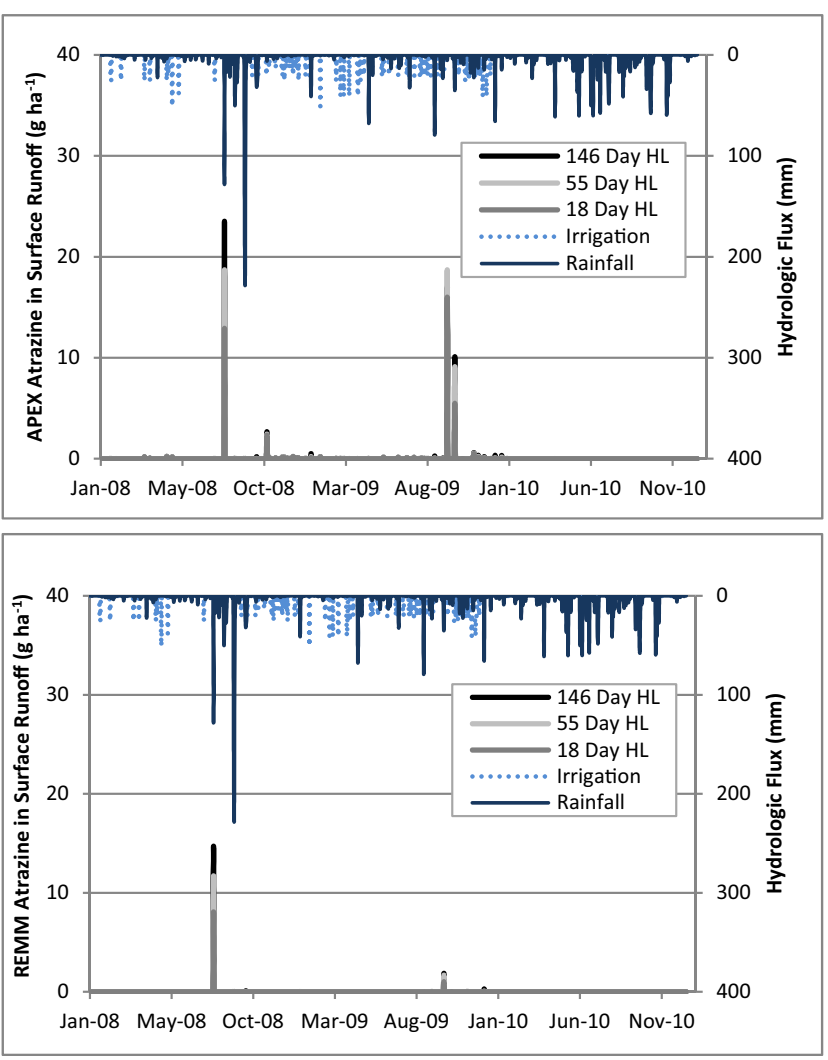

Fig. 2 Atrazine (18-, 55-, and 146-day DT ${ }_{50}$ ) transport in surface runoff from the APEX and REMM

transported in surface runoff was between 0 and $23 \mathrm{~g} \mathrm{ha}^{-1}(0$ and $0.02 \mathrm{lb} \mathrm{ac}^{-1}$ ) for all scenarios (Fig. 2). Atrazine transport in surface runoff was significantly greater $(p<0.001)$ when the default $\mathrm{DT}_{50}, 146$ days, was used. When the measured $\mathrm{DT}_{50}$ was used, either 55 or 18 days, total loads were not significantly different $(p>0.05)$. In all cases, the largest simulated atrazine losses in surface runoff occurred as a result of Tropical Storm Faye (August 15, 2008) when the area received $128 \mathrm{~mm}$ of rainfall in $24 \mathrm{~h}$ (Fig. 3).

Intense rainfall during the wet season (June-October) is common in Puerto Rico $[13,39,40]$ and is a major source of runoff which promotes water pollution from agricultural areas [13]. Two days prior to Tropical Storm Faye, $962 \mathrm{~g} \mathrm{ha}^{-1}$ $\left(0.86 \mathrm{lb} \mathrm{ac}^{-1}\right)$ of atrazine was applied to SA3. APEX simulations indicated that of the total amount of atrazine applied to SA3, $3 \%$ $\left(50 \mathrm{~g}\right.$ atrazine $\left.\mathrm{ha}^{-1}\right)$ was lost in surface runoff during the storm event when $\mathrm{DT}_{50}$ was 18 days, $4 \%\left(80 \mathrm{~g}\right.$ atrazine $\left.\mathrm{ha}^{-1}\right)$ with the 55-day $\mathrm{DT}_{50}$ scenario, and $5 \%\left(90 \mathrm{~g}\right.$ atrazine $\left.\mathrm{ha}^{-1}\right)$ for the 146day $\mathrm{DT}_{50}$ scenario. The simulated proportion of atrazine applied that was in surface runoff was greater in some instances than measured losses from small plots under simulated tropical rain events in Brazil where $2 \%$ of the applied mass was transported [41]. Subsequent runoff events approximately 30 days after Tropical Storm Faye cumulatively produced approximately $8 \mathrm{~g}$ atrazine ha ${ }^{-1}(0.02 \%$ of atrazine applied $)$ in surface runoff from the three simulation $\mathrm{DT}_{50}$ scenarios (Fig. 3c). Similar findings 
Fig. 3 Atrazine transport and discharge during Tropical Storm Faye (August 15, 2008) and Hurricane Kyle (September 2125, 2008) for the APEX (a), REMM (b), and REMM highlighting Hurricane Kyle (c)
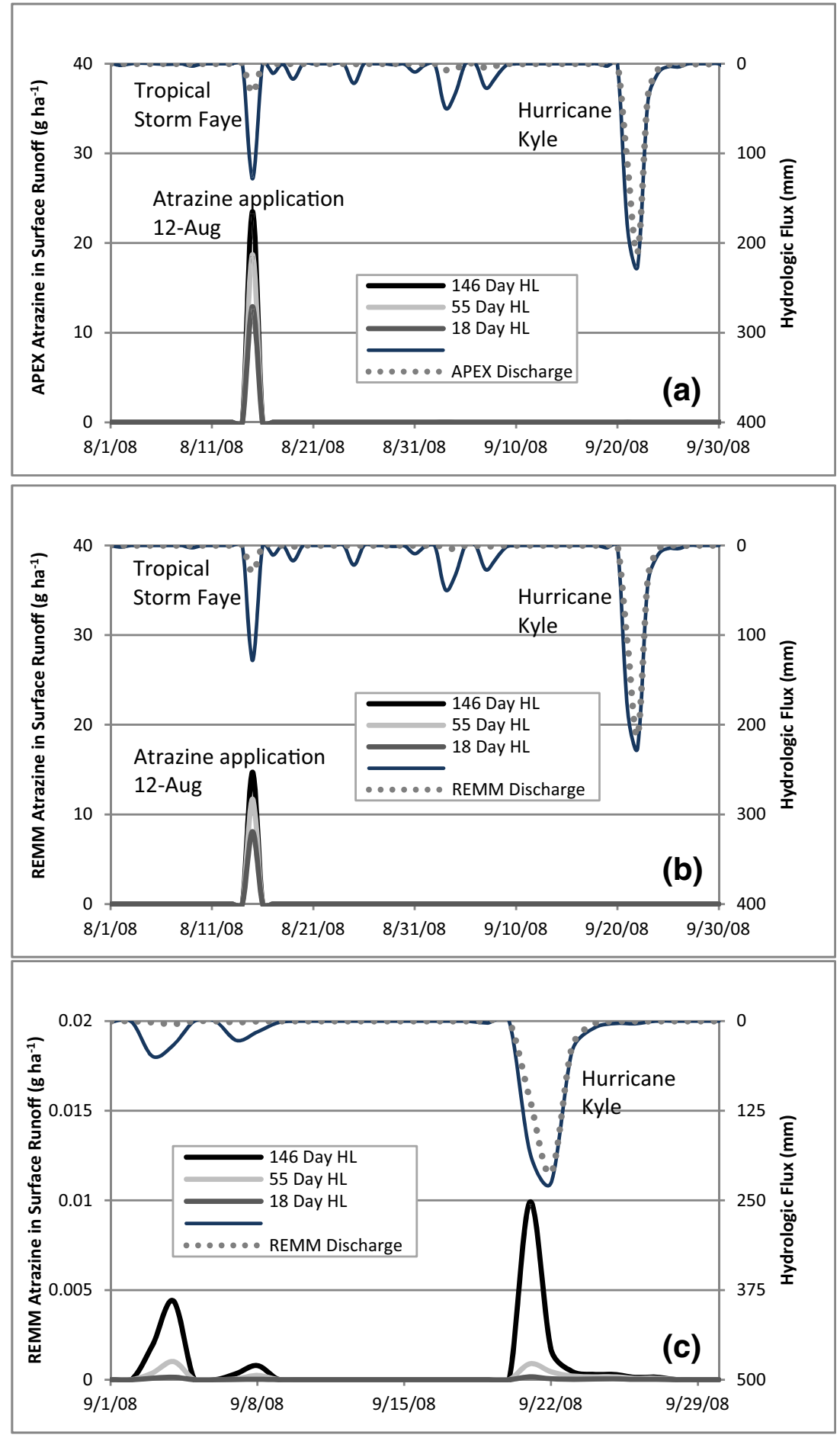

have been reported for runoff events after herbicide application in various field studies, i.e., a decrease in atrazine transport in surface runoff for a subsequent runoff event in both temperate [42-45] and tropical climates [41].

Simulated APEX sediment loads were also reflective of weather patterns. The annual APEX sediment transport in 2008 (28 $\mathrm{Mg} \mathrm{ha}^{-1}\left[12.5 \mathrm{t} \mathrm{ac}^{-1}\right]$ ) was greatest with $93 \%$ of sediment transported due to Hurricane Kyle on September 21-25, 2008
(25.7 $\left.\mathrm{Mg} \mathrm{ha}^{-1}\left[11.5 \mathrm{t} \mathrm{ac}^{-1}\right]\right)$. The computed APEX sediment transport in 2009 and 2010 was 0.7 and $0.01 \mathrm{Mg} \mathrm{ha}^{-1}$, respectively (0.3 and $0.005 \mathrm{t} \mathrm{ac}^{-1}$, respectively) [26].

The APEX-simulated sediment-bound atrazine transport was much less than dissolved atrazine in surface runoff (Table 2). The mass of sediment-bound atrazine for each of the three $\mathrm{DT}_{50}$ dissipation scenarios was less than $0.02 \%$ of atrazine applied. The APEX-simulated atrazine transport in 
subsurface flow was less than $0.05 \mathrm{~g} \mathrm{ha}^{-1}\left(0.00004 \mathrm{lb} \mathrm{ac}^{-1}\right)$ for all scenarios (Table 2). There was no significance $(p>0.05)$ in the sediment-bound atrazine between the three $\mathrm{DT}_{50}$ scenarios; however, the mass of sediment-bound atrazine was greatest from the 146-day $\mathrm{DT}_{50}$ scenario. The low APEXsimulated subsurface transport was consistent with the relatively low groundwater concentrations reported elsewhere [14].

Overall, the total mass per area of atrazine transported using the 18-day $\mathrm{DT}_{50}$ in the APEX was $40.7 \mathrm{~g} \mathrm{ha}^{-1}$. This was 25 and $33 \%$ less than that for the 55- and 146-day DT ${ }_{50}$ scenarios, respectively. All estimates were in the same range as those observed in other studies indicating a total loss of about $1 \%$ of atrazine applied [43, 46, 47]. In addition, a large portion up to $93 \%$ of the total was lost during a single storm event that occurred within 2 days of an atrazine application. The APEX simulations showed the importance of application timing in relation to storm events as well as the need to accurately simulate the dissipation of atrazine.

\subsection{REMM Simulations}

Generally, the greater the atrazine loading into the buffer, the greater the simulated output (Table 2). In total, the mass of atrazine transported from the REMM-simulated buffer was $23 \%$ of the mass input from the upland. Nearly all simulated transports within the buffer were in the dissolved form in surface flow. The simulated mass transported in subsurface flow was less than $0.001 \mathrm{~g} \mathrm{ha}^{-1}$ for the three loading scenarios. Sediment-bound atrazine transport was also low and primarily due to relatively low sediment loads [26] and atrazine's low soil organic matter water partition coefficient. A notable feature of simulations was buffer performance during the extreme event, Tropical Storm Faye (August 15, 2008). In this event, the REMM estimated $37 \%$ retention of atrazine in the buffer, whereas for the entire study period, atrazine retention was $77 \%$. Arora et al. [44] reported a similar trend in atrazine retention in a vegetative buffer 2 days following an atrazine application and rainfall event in Iowa.

The extreme event coincided with detection of atrazine and its degradant, desethylatrazine (DEA), in near-shore estuary samples that were collected 4 days following Tropical Storm Faye. As previously mentioned, data suggests that application timing (Table 1) coupled with a significant rainfall event (128 mm [5 in.] in $24 \mathrm{~h}$ ) was a likely cause for the detection [14]. REMM simulations indicated that $11.7 \mathrm{~g} \mathrm{ha}^{-1}\left(40 \mu \mathrm{g} \mathrm{L}^{-1}\right)$ of atrazine was transported from the buffer to the estuary on the day of the rain event. The simulated volume-weighted concentration in runoff was $40 \mu \mathrm{g} \mathrm{L}^{-1}$, nearly 100 times the highest measured value in estuary samples. The nearly 100 -fold difference between the REMM predicted and the measured value was likely due to the fact that there were four full tidal cycles between the storm event and sample collection indicating substantial potential for dilution. REMM simulation of subsequent runoff events indicated little to no atrazine transport. This was likely due to rapid soil dissipation of atrazine; therefore, when runoff occurred, there was little or no atrazine in field soil available for runoff and any atrazine present was attenuated in the buffer.

One of the primary uses of the REMM is to evaluate buffer width and how the width of the overall buffer and the three zones are related to reductions in edge-of-field loadings. Field studies have shown a range of herbicide reduction ( 8 to $98 \%$ ) through vegetative buffer systems based on width [3-5, 45]. Wider vegetative strips generally reduce herbicide loads more as a result of longer contact with vegetation, increased infiltration, and increased deposition of suspended solids. However, it appears to be the relationship between the amounts attenuated and buffer width decreases exponentially [36]. For atrazine, studies have indicated that the dominant mechanism for reduction in buffers is via infiltration [48, 49]. As mentioned previously, in the case of this simulation, the dominant transport mechanism for atrazine was via surface runoff mostly associated with tropical storm events that came with heavy rains over a short period of time (Fig. 3).

The APEX-simulated total mass of atrazine transported under most likely atrazine loading rates, i.e., when measured field soil dissipation rates were used (18-day $\mathrm{DT}_{50}$ ), and at the edge of each buffer zone is shown in Fig. 4. Total mass of atrazine transport from the field was $40.9 \mathrm{~g} \mathrm{ha}^{-1}\left(0.04 \mathrm{lb} \mathrm{ac}^{-1}\right)$ with $18.1 \mathrm{~g} \mathrm{ha}^{-1}\left(0.02 \mathrm{lb} \mathrm{ac}^{-1}\right)$ transported from zone 3 , $12.5 \mathrm{~g} \mathrm{ha}^{-1}\left(0.01 \mathrm{lb} \mathrm{ac}^{-1}\right)$ transported from zone 2, and $1 \mathrm{~g} \mathrm{ha}^{-1}\left(0.0009 \mathrm{lb} \mathrm{ac}^{-1}\right)$ transported from zone 1. Over the entire study period, simulations indicated that there were significant differences $(p<0.001)$ in the atrazine transport between the upland fields and each of the buffer zones. There

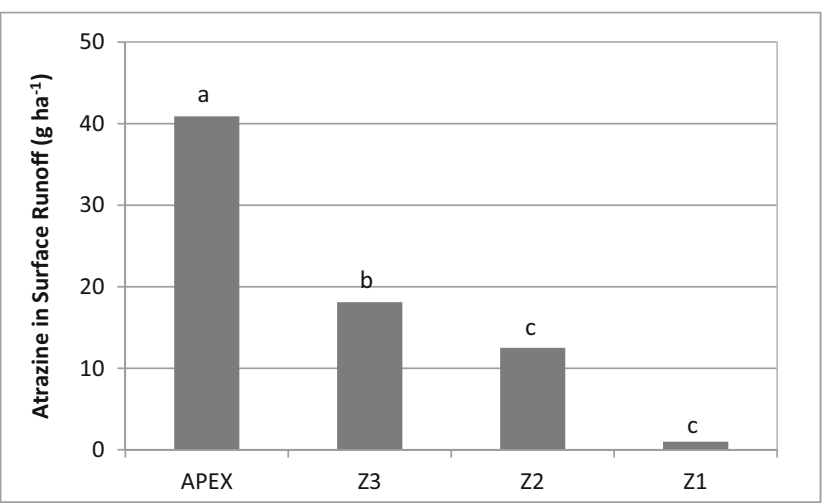

Fig. 4 Total atrazine output from the APEX (18-day $\mathrm{DT}_{50}$ ) and REMM $\left(55\right.$-day $\mathrm{DT}_{50}$ ) by zone. Zone values are the total output per area from the zone. Values with the same letter are not significantly different based on the Kruskal-Wallis test 
were also significant differences $(p<0.001)$ between atrazine from zone 3 (perennial grass) and zones 2 (mixed forest) and 1 (mixed forest). Simulated atrazine transported from the upland was reduced by $56 \%$ at the edge of zone 3 , by $70 \%$ at the edge of zone 2 , and by $77 \%$ at the edge of zone 1 . The greatest reduction $(p<0.001)$ of atrazine occurred in zone 3 which consisted of perennial grass and was consistent with field studies where grass buffers at the upslope edge of forest buffers reduced pesticide loadings [4, 5, 45].

Atrazine reduction between the edge of zone 3 (perennial grass) and zone 2 was $31 \%$, while it was $26 \%$ between the edge of zone 2 (mixed forest) and zone 1 (mixed forest). There was a significant difference $(p<0.001)$ between the output from zone 3 and zone 2 , but there was no significant difference $(p>0.05)$ between the outputs from zone 2 and zone 1 (Fig. 4). The combined width of zone 3 and zone 2 was $80 \mathrm{~m}(262 \mathrm{ft})$ compared to $157 \mathrm{~m}(515 \mathrm{ft})$ for the combined width of all three zones. Another aspect of buffer efficiency is buffer placement.

Williams et al. [26] calibrated and validated the hydrologic flux of the APEX and REMM using measured daily water table fluctuation. The overall reduction in water flow for the 3 -year study period was $16 \%$. The REMM simulated an $8 \%$ reduction of surface runoff for Tropical Storm Faye (August $15,2008)$, but only a $1 \%$ reduction in runoff from Hurricane Kyle (September 21-25, 2008) (Fig. 3). Due to the antecedent soil moisture conditions of the riparian buffer when Hurricane Kyle occurred and the intensity of the rainfall events, the reduction in surface runoff was small for Tropical Storm Faye and even smaller for Hurricane Kyle. Up until Tropical Storm Faye, the surface runoff reduction in the REMM was $100 \%$ (Fig. 3b). A series of rain events occurring shortly after Tropical Storm Faye produced little to no surface runoff entering the buffer (Fig. 3b). However, saturated conditions in the buffer generated surface runoff from the buffer. Year 2009 was a dry year, and daily surface runoff reductions in the REMM ranged between 53 and $100 \%$ with the exception of one rainfall event that occurred on December 25, 2009, that had $66 \mathrm{~mm}$ of rain with a $2 \%$ reduction of surface runoff. Daily surface runoff reductions ranged between 18 and $100 \%$ with an average of $82 \%$ until October 6, 2010. Following this time, there was an increase in surface runoff by as much as $99 \%$. Similar trends were observed in [50], where they observed that the ratio of runoff versus precipitation, for consecutive storm events, was generally larger for a subsequent rainfall event than the previous day's event. The REMMsimulated surface runoff suggests that the riparian has the potential to significantly reduce surface runoff. However, intense rainfall events such as tropical storms and hurricanes have the potential to transport more runoff from the riparian zone to the bay (see Fig. 3b, c).

Finally, with regard to atrazine dissipation, the use of the measured field data appeared to provide a more realistic estimate of atrazine loss from the field. However, actual losses may have been less. The first-order kinetic model for dissipation that is used in both the APEX and REMM [23, 29, 35] provided a relatively poor fit to measured dissipation data (data not published). Data were more effectively described using a non-linear model. In this case, the measured $\mathrm{DT}_{50}$ in field soil samples was 2 days [14]. This suggests that atrazine transport to Jobos Bay may be lower than indicated with the linear first-order models used to describe atrazine dissipation kinetics in the APEX and REMM and that model accuracy could be improved by incorporating alternate kinetic models for pesticide dissipation in soil.

\section{Summary and Conclusions}

The sensitivity of APEX to variations in atrazine $\mathrm{DT}_{50}$ values and how loads may be attenuated by a buffer between the agricultural field and a mangrove wetland was evaluated using the REMM. The use of the two models in tandem provided an assessment of the capacity of a three-zone vegetated buffer to reduce atrazine transport from a farm field to Jobos Bay. There was as much as a $33 \%$ difference in the atrazine output between the upland field simulations when the measured versus default atrazine $\mathrm{DT}_{50}$ values were used. REMM simulations indicated that the buffer system reduced atrazine transport by as much as $77 \%$ (18-day $\mathrm{DT}_{50}$ ) in surface runoff, $100 \%$ in subsurface flow, and by as much as $50 \%$ in sediment transport for the 3 years of the simulations. Percent reduction of atrazine in the buffer was less for large rainfall-runoff events. Atrazine application timing in relation to rainfall events was also shown to have a large impact on simulated field and buffer system losses. Accelerated dissipation as measured in the field [14] would be expected to lead to lower transport. The modeling results helped confirm this. The REMM-simulated buffer had the most atrazine reduction in zone 3 which consisted of perennial grasses. REMM simulations also indicated that a $157-$ $\mathrm{m}$ (515-ft) wide buffer (all three zones) was not significantly $(p>0.05)$ more effective than an 80-m (262-ft) wide buffer (zones 3 and 2 only). However, a shorter buffer width could also change the hydrology of the system by decreasing travel time leading to greater overland flow which may have unexpected adverse effects on atrazine transport to adjacent water bodies.

The incorporation of vegetated buffers in coastal tropical ecosystems has great implications with regard to conservation management. By design, these buffers regulate the flow of upland water entering adjacent water bodies but in tropical ecosystems where intense rainfall occurs over a period of days, buffers may do little in attenuating agricultural runoff during storm events $[26,51]$. Buffers, like any conservation practice, are complementary to effective pesticide management. Further investigations should include simulations that 
would entail additional buffer width scenarios, especially in tropical climates that experience intensive runoff events at specific periods of the year. Lastly, investigations involving the use of predictive models to simulate pesticide transport should consider the sensitivity of these tools to variations in $\mathrm{DT}_{50}$ values as they would impact decisions regarding conservation management.

\section{References}

1. Lewis, S. E., Schaffelke, B., Shaw, M., Bainbridge, Z. T., Rohde, K. W., Kennedy, K., Davis, A. M., Masters, B. L., Devlin, M. J., Mueller, J. F., \& Brodie, J. E. (2012). Assessing the additive risks of PSII herbicide exposure to the Great Barrier Reef. Marine Pollution Bulletin, 65, 280-291.

2. Lowrance, R., Altier, L. S., Newbold, J. D., Schnabel, R. R., Groffman, P. M., Denver, J. M., Correll, D. L., Gilliam, J. W., Robinson, J., Brinsfield, R., Staver, K., Lucas, W., \& Todd, A. (1995). Water quality functions of riparian forest buffer systems in the Chesapeake Bay Watershed (U.S. Environmental Protection Agency Report EPA 903-R-95-004). Washington, D.C.: U.S.EPA.

3. Schmitt, T. J., Dosskey, M. G., \& Hoagland, K. D. (1999). Filter strip performance and processes for different vegetation, widths, and contaminants. Journal of Environmental Quality, 28, 14791489.

4. Vellidis, G., Lowrance, R., Gay, P., \& Wauchope, R. D. (2002). Herbicide transport in a restored riparian forest buffer system. Transactions of American Society of American Engineers, 45, 8997.

5. Gay, P. A., Vellidis, G., \& Delfino, J. J. (2006). The attenuation of atrazine and its major degradation products in a restored riparian buffer. Transactions of the American Society of Agricultural Engineers, 49, 1323-1339.

6. Gilliam, J. W., Osmond, D. L., \& Evans, R. O. (1997). Selected agricultural best management practices to control nitrogen in the Neuse River Basin (North Carolina Agricultural Research Service Technical Bulletin 311). Raleigh, NC: North Carolina State University.

7. Lowrance, R., Williams, R. G., Inamdar, S. P., Bosch, D. D., \& Sheridan, J. M. (2001). Evaluation of coastal plain conservation buffers using the Riparian Ecosystem Management Model. Journal of American Water Resources, 37, 1445-1455.

8. Mickelson, S. K., Baker, J. L., \& Ahmed, S. I. (2003). Vegetative filter strips for reducing atrazine and sediment runoff transport. Journal Soil Water Conservation., 58, 359-367.

9. Seybold, C., Mersie, W., \& Delorem, D. (2001). Removal and degradation of atrazine and metolachlor by vegetative filter strips on clay loam soil. Communications of Soil Science Plant Analysis, $32,723-737$

10. Krutz, L. J., Senseman, S. A., Zablotowicz, R. M., \& Matocha, M. A. (2005). Reducing herbicide runoff from agricultural fields with vegetative filter strips: a review. Weed Science, 53, 353-367.

11. Welsch, D.J. (1991). Riparian forest buffers. USDA-FS Publ. No. NA-PR-07-91. Radnor, PA. http://www.na.fs.fed.us/spfo/pubs/n resource/buffer/cover.htm. Accessed June 1, 2011

12. U.S. Department of Agriculture, Natural Resource Conservation Service (NRCS). (1995). Riparian forest buffer, 392. Seattle, Washington: NRCS Watershed Science Institute.

13. Whitall, D. R., Costa, B. M., Bauer, L. J., Dieppa, A., \& Hile, S. D. (2011). A Baseline assessment of the ecological resources of Jobos
Bay, Puerto Rico (NOAA Technical Memorandum NOS NCCOS 133, p. 188). Maryland: Silver Spring.

14. Potter, T. L., Bosch, D. D., Dieppa, A., Whitall, D. R., \& Strickland, T. C. (2013). Atrazine fate and transport within the coastal zone in southeastern Puerto Rico. Marine Pollution Bulletin, 67(1-2), 3644. doi:10.1016/j.marpolbul.2012.12.004.

15. Mausback, M. J., \& Dedrick, A. R. (2004). The length we go measuring environmental benefits of conservation practices. Journal of Soil and Water Conservation, 59, 96-103.

16. Cho, J., Vellidis, D. D., Lowrance, R. R., \& Strickland, T. (2010). Water quality effects of simulated conservation practice scenarios in the Little River Experimental Watershed. Journal of Environmental Quality, 65, 463-473.

17. Palmer, M. D. (2001). Water quality modeling: a guide to effective practice (p. 158). Washington, D.C.: World Bank.

18. Dubus, I. G., Brown, C. D., \& Beulke, S. (2003). Sources of uncertainty in pesticide fate modeling. Science of the Total Environment, 317, 53-72.

19. Chinkuyu, A., Meixner, T., Gish, T., \& Daughtry, C. (2005). Prediction of pesticide losses in surface runoff from agricultural fields using GLEAMS and RZWQM. Transactions of the American Society of Agricultural Engineers, 48, 585-589.

20. Dann, R. L., Close, M. E., Lee, R., \& Pang, L. (2006). Impact of data quality and model complexity on prediction of pesticide leaching. Journal of Environmental Quality, 35, 628-640.

21. Arbeli, Z., \& Fuentes, C. L. (2007). Accelerated biodegradation of pesticides: an overview of the phenomenon, its basis and possible solutions; and a discussion on the tropical dimension. Crop Protection, 26, 1733-1746.

22. Krutz, L. J., Shaner, D., Acinelli, C., Zablotowicz, R. M., \& Henry, B. (2008). Atrazine dissipation in $s$-triazine-adapted and nonadapted soil from Colorado and Mississippi: implications of enhanced degradation on atrazine fate and transport parameters. Journal of Environmental Quality, 37, 848-857.

23. Williams, J. R., Arnold, J. G., \& Srinivasan, R. (2000). The APEX model (BREC Rep. No. 00-06). Temple, Texas: Texas A\&M University. Blackland Research and Extension Center.

24. Inamdar, S. P., Sheridan, J. M., Williams, R. G., Bosch, D. D., Lowrance, R. R., Altier, L. S., \& Thomas, D. L. (1999). Riparian Ecosystem Management Model (REMM): I. Testing of the hydrologic component for a coastal plain riparian system. Transactions of the American Society of Agricultural Engineers, 42, 1679-1689.

25. Inamdar, S. P., Lowrance, R. R., Altier, L. S., Williams, R. G., \& Hubbard, R. K. (1999). Riparian Ecosystem Management Model (REMM): II. Testing of the water quality and nutrient cycling component for a coastal plain riparian system. Transactions of the American Society of Agricultural Engineers, 42, 1691-1707.

26. Williams, C. O., Lowrance, R., Bosch, D. D., Williams, J. R., Benham, E., Dieppa, A., Hubbard, R., Mas, E., Potter, T., Sotomayor, D., Steglich, E. M., Strickland, T., \& Williams, R. G. (2013). Hydrology and water quality of a field and riparian buffer adjacent to a mangrove wetland in Jobos Bay Watershed, Puerto Rico. Journal of Ecological Engineering, 56, 60-68. doi:10.1016/j. ecoleng.2012.09.005.

27. National Climatic Data Center (NCDC). (2010). (Online). NOAA satellite and information service. http://www7.ncdc.noaa.gov/ CDO/cdo. Accessed 27 September 2010

28. Soil Survey Staff, Natural Resources Conservation Service, United States Department of Agriculture. Soil Survey Geographic (SSURGO) Database for Puerto Rico. Available online at http:// soildatamart.nrcs.usda.gov. Accessed September 2010.

29. Williams, J. R., Arnold, J. G., \& Steglich, E. M. (2008). The APEX theoretical documentation (BREC Rep. No. 2008-17). Temple, Texas: Texas A\&M University. Blackland Research and Extension Center. 
30. U.S. Department of Agriculture, Soil Conservation Service (SCS) (1972). National engineering handbook, hydrology section 4, chapters 4-10

31. Green, W. H., \& Ampt, G. H. (1911). Studies on soil physics: 1. Flow of air and water through soils. Journal Agricultural Science, 4, 1-24.

32. National Estuarine Research Reserve System (NERRS) (2009). (Online). Centralized Data Management Office. http://cdmo. baruch.sc.edu/. Accessed 5 October 2009

33. National Cooperative Soil Survey (NCSS), National Cooperative Soil Characterization Database. Available online at http://ssldata. nrcs.usda.gov. Accessed March 12, 2009.

34. Schaap, M. G., Leij, F. J., \& van Genuchten, M. T. (2001). ROSETTA: a computer program for estimating soil hydraulic parameters with hierarchical pedotransfer functions. Journal of Hydrology, 251, 163-176.

35. Lowrance, R., Altier, L. S., Williams, R. G., Inamdar, S. P., Sheridan, J. M., Bosch, D. D., Hubbard, R. K., \& Thomas, D. L. (2000). REMM: the riparian ecosystem management model. Journal of Soil and Water Conservation, 55, 27-34.

36. Potter, T. L., Lowrance, R. R., Bosch, D. D., \& Williams, R. G. (2011). Estimating pesticide retention efficacy for edge of field buffers using the riparian ecosystem management model (REMM) in a southeastern coastal plain landscape. In K. S. Goh et al. (Eds.), Pesticide mitigation strategies for surface water quality (pp. 259271). Washington, D.C.: American Chemical Society Symposium Series 1075, American Chemical Society.

37. Racke, K. D., Skidmore, M. W., Hamilton, D. J., Unsworth, J. B., Miyamoto, J., \& Cohen, S. Z. (1997). Pesticide fate in tropical soils. Pure Application Chemistry., 69, 1349-1371.

38. SAS Institute, Inc. (2008). SAS/STAT user's guide, ver. 9.2. Cary, N.C.: SAS Institute.

39. Ewel, J.J., \& Whitmore, J.L. (1973). The ecological life zones of Puerto Rico and the U.S. Virgin Islands. USDA Forest Service, Institute of Tropical Forestry. Forest Service Research Paper ITF18, p. 72.

40. Zitello, A.G., Whitall, D.R., Dieppa, A., Christensen, J.D., Monaco, M.E. Rohmann, S.O. (2008). Characterizing Jobos Bay, Puerto Rico: a watershed modeling analysis and monitoring plan. National Oceanic and Atmospheric Association Technical Memorandum NOS NCCOS 76, p. 81
41. Correia, F. V., Macrae, A., Guilherme, L. R. G., \& Langenbach, T. (2007). Atrazine sorption and fate in an Ultisol from humid tropical Brazil. Chemosphere, 67, 847-854.

42. Klaine, S. J., Hinman, M. L., Winkelmann, D. A., Sauer, K. R., Martin, J. R., \& Moore, L. W. (1988). Characterization of agricultural non-point pollution: pesticide migration in a west Tennessee watershed. Environmental Toxicological Chemistry, 7, 609-614.

43. Pantone, D. J., Young, R. A., Buhler, D. D., Eberlein, C. P., Koskinen, W. C., \& Forcella, F. (1992). Water quality impacts associated with pre- and post-emergence applications of atrazine in maize. Journal of Environmental Quality, 21, 567-573.

44. Arora, K., Mickelson, S. K., Baker, J. L., Tierney, D. P., \& Peter, C. J. (1996). Herbicide retention by vegetative buffer strips from runoff under natural rainfall. Transactions of the American Society of Agricultural Engineers, 30, 2155-2162.

45. Lowrance, R., Vellidis, G., Wauchope, R. D., Gay, P., \& Bosch, D. D. (1997). Herbicide transport in a managed riparian forest buffer system. Transactions of American Society of Agricultural Engineers, 40, 1047-1057.

46. Wauchope, R. D. (1978). The pesticide content of surface water draining from agricultural fields-a review. Journal of Environmental Quality, 7, 459-472.

47. Harmon, W. L., Wang, E., \& Williams, J. R. (2004). Reducing atrazine losses: water quality implications of alternative runoff control practices. Journal of Environmental Quality, 33, 7-12.

48. Krutz, L. J., Senseman, S. A., Dozier, M. C., Hoffman, D. W., \& Tierney, D. P. (2003). Infiltration and adsorption of dissolved atrazine and atrazine metabolites in buffalograss filter strips. Journal of Environmental Quality, 32, 2319-2324.

49. Lafrance, P., Caron, E., \& Bernard, C. (2013). Impact of grass filter strips length on exported dissolved masses of metolachlor, atrazine and deethylatrazine: a four-season study under natural rain conditions. Soil Use and Management, 29, 87-97.

50. Wang, X., Hoffman, D. W., Wolfe, J. E., Williams, J. R., \& Fox, W. E. (2009). Modeling the effectiveness of conservation practices at Shoal Creek watershed, Texas, using APEX. Transactions of American Society of Agricultural Engineers, 52(4), 1181

51. McKergow, L. A., Prosser, I. P., Grayson, R. B., \& Heiner, D. (2004). Performance of grass and rainforest riparian buffers in the wet tropics, Far North Queensland. 1. Riparian hydrology. Australian Journal of Soil Research, 42, 473-484. 